\title{
Analisis Kemampuan Pemecahan Masalah Matematika dan Self-Efficacy Siswa SMP Negeri di Kabupaten Ciamis
}

\author{
Ratna Widianti Utami ${ }^{1}{ }^{*}$, Dhoriva Urwatul Wutsqa ${ }^{1}$ \\ ${ }^{1}$ Program Studi Pendidikan Matematika, Program Pascasarjana, Universitas Negeri Yogyakarta. Jalan \\ Colombo No. 1, Karangmalang, Yogyakarta 55281, Indonesia. \\ * Corresponding Author. Email: ratnautami24@gmail.com \\ Received: 17 July 2017; Revised: 2 November 2017; Accepted: 9 November 2017
}

\begin{abstract}
Abstrak
Penelitian ini bertujuan untuk mendeskripsikan kemampuan pemecahan masalah matematika, self-efficacy siswa dan hubungan antara kemampuan pemecahan masalah dan self-efficacy siswa kelas VIII SMP Negeri di Kabupaten Ciamis. Penelitian ini adalah penelitian survei. Subjek penelitian terdiri dari 389 siswa kelas VIII SMP Negeri di Kabupaten Ciamis yang berasal dari 13 sekolah dengan kategori strata tinggi, sedang dan rendah. Sampel dalam penelitian ini ditentukan dengan stratified proporsional random sampling. Hasil penelitian menunjukkan bahwa 389 siswa yang dijadikan subjek penelitian memiliki kemampuan pemecahan masalah dalam kriteria rendah. Faktorfaktor yang menyebabkan keadaan tersebut diantaranya adalah siswa kurang memahami informasi pada soal, siswa kurang mampu membuat model matematis, dan siswa kurang teliti dalam menyelesiakan soal. Rata-rata self-efficacy siswa berada pada kriteria sedang, yaitu 91,17. Hubungan kemampuan pemecahan masalah matematika dan self-efficacy siswa termasuk kategori sangat rendah karena nilai $r$ sebesar 0,104.
\end{abstract}

Kata Kunci: kemampuan pemecahan masalah, self-efficacy siswa

\section{An Analysis of Mathematics Problem-solving Ability and Self-Efficacy Students of Junior High School in Ciamis Regency}

Abstract
This study aims to describe the mathematics problem-solving ability, self-efficacy of students and the relationship between the problem-solving and self-efficacy of the grade VIII students of the junior high school in Ciamis Regency. This study was categorized as survey research. The research subjects were 389 junior high school grade VIII in Ciamis Regency from 13 schools which were categorized as high, moderate and low schools. The research sample was selected by means of the stratified proportional random sampling technique. The results of the study are as follows, 389 students as the research subject have low criteria in problem-solving ability. Factors that cause this situation, such as students are less understanding of existing information on the problem, students are less able to make mathematical models, and students are less thorough in problem-solving. The average of students' self-efficacy was at moderate criteria, 91.17. The relationship between problemsolving ability and self-efficacy of students was at very low criteria because of the r-value of 0.104.

Keywords: problem-solving ability, self-efficacy students

How to Cite: Utami, R., \& Wutsqa, D. (2017). Analisis kemampuan pemecahan masalah matematika dan selfefficacy siswa SMP negeri di Kabupaten Ciamis. Jurnal Riset Pendidikan Matematika, 4(2), 166-175. doi:http://dx.doi.org/10.21831/jrpm.v4i2.14897

Permalink/DOI: http://dx.doi.org/10.21831/jrpm.v4i2.14897 


\section{PENDAHULUAN}

Matematika merupakan salah satu mata pelajaran yang wajib dipelajari oleh siswa pada setiap jenjang pendidikan. Pentingnya matematika tidak hanya dipelajari di dalam kelas, namun matematika dekat dengan kegiatan kehidupan sehari-hari. Seperti yang disebutkan dalam Permendikbud Nomor 58 Tahun 2014 bahwa matematika merupakan ilmu universal yang berguna bagi kehidupan manusia dan juga mendasari perkembangan teknologi modern, serta mempunyai peran penting dalam berbagai disiplin dan memajukan daya pikir manusia. Salah satu kemampuan matematis yang harus dimiliki siswa adalah kemampuan pemecahan masalah matematika NCTM (2000, p. 29). Kemampuan pemecahan masalah menjadi salah satu tujuan pembelajaran matematika yang harus dicapai oleh siswa. Dalam kehidupan sehari-hari secara sadar maupun tidak sadar, setiap hari kita dihadapkan dengan berbagai permasalahan yang menuntut kemampuan pemecahan masalah. Pemecahan masalah merupakan suatu usaha untuk mencapai tujuan yang diinginkan dan tidak secara otomatis diketahui cara yang tepat untuk tujuan tersebut (Nitko, 2011, p. 231). Dengan pemecahan masalah siswa akan belajar untuk menyusun strategi yang sesuai untuk menyelesaikan permasalahan yang mereka hadapi. Didukung dengan kajian Pimta, Tayruakham \& Nuangchalerm (2009, p. 381) pemecahan masalah dianggap sebagai jantung dalam pembelajaran matematika. Senada dengan pernyataan Burchartz \& Stein (Yazgan, 2015, p.1807) pemecahan masalah selalu memainkan peran penting, karena semua kegiatan kreatif matematika menuntut tindakan pemecahan masalah.

Salah satu hasil tes yang mengukur kemampuan pemecahan masalah siswa dapat dilihat dari hasil tes yang dilakukan oleh dua studi internasional, yaitu Programme for International Student Assesment (PISA) dan Trends in International Mathematics and Science Study (TIMSS). Laporan PISA pada tahun 2015, skor matematika siswa Indonesia berada pada posisi 63 dari 70 negara peserta. Pada laporan TIMSS tahun 2011, siswa Indonesia berada pada posisi 38 dari 42 negara peserta. Hal ini menunjukkan perlunya meningkatkan kemampuan matematis siswa yang salah satunya kemampuan pemecahan masalah.

Hasil Ujian Nasional matematika juga dapat dijadikan gambaran kemampuan pemecahan masalah siswa. Salah satunya melihat hasil UN di Kabupaten Ciamis. Berdasarkan laporan dari BSNP, hasil UN tingkat SMP di Kabupaten Ciamis selama tiga tahun terakhir merupakan mata pelajaran paling rendah dibandingkan mata pelajaran yang diujikan lainnya, sesuai pada Tabel 1. Keadaan ini menunjukkan siswa belum menguasai materi matematika yang diujikan. Dengan kata lain, dapat diindikasikan siswa kurang mampu memahami dan memecahkan permasalahan matematika yang diberikan.

Tabel 1. Hasil UN di Kabupaten Ciamis

\begin{tabular}{ccccc}
\hline Nilai & Tahun & Tahun & Tahun & Kriteria \\
Ujian & $\mathbf{2 0 1 3 / 2 0 1 4}$ & $\mathbf{2 0 1 4 / 2 0 1 5}$ & $\mathbf{2 0 1 5 / 2 0 1 6}$ & \\
Rata-rata & 5,68 & 55,10 & 66,26 & Cukup \\
Terendah & 2,75 & 35,00 & 45,00 & Cukup \\
Tertinggi & 10,00 & 100,00 & 97,50 & Cukup \\
\hline
\end{tabular}

Kemampuan pemecahan masalah erat kaitannya dengan keyakinan siswa dalam menyelesaikan soal, karena keyakinan yang dimiliki siswa dalam pemecahan masalah akan mempengaruhi hasil belajar siswa. Hasil penelitian berdasarkan Leder, 1987; McLeod, 1992; Reyes, 1984 menunjukkan berbagai sikap dan keyakinan tentang matematika berpengaruh pada prestasi matematika (Yates, 2002, p.4). Keyakinan ini disebut self-efficacy. Menurut Bandura (2009, p.2) self-efficacy merupakan keyakinan seseorang mengenai kemampuan untuk menyusun dan menyelesaikan tindakan yang dibutuhkan dalam mengatur situasi yang akan datang. Self-efficacy mempengaruhi bagaimana seseorang berpikir, merasakan, memotivasi diri sendiri dan bertindak. Dari pernyataan tersebut, maka dapat disimpulkan bahwa selfefficacy merupakan keyakinan seseorang dalam melakukan tindakan. Self-efficacy siswa mempengaruhi keberhasilan dan kegagalan dalam matematika, selain pengaruh dari perbedaan individu pada motivasi dan prestasi siswa dalam matematika. Hal ini didukung dengan pernyataan Lunenburg (2011, pp.1-2) bahwa self-efficacy memiliki pengaruh yang kuat terhadap pembelajaran, motivasi, dan kinerja, karena dengan self-efficacy yang dimiliki seseorang akan berusaha mencoba untuk belajar dan melakukan tugas yang mereka percaya akan dapat berhasil. Sesuai dengan hasil penelitian Liu \& Koirala (2009, p. 9) menunjukkan bahwa self-efficacy dan prestasi matematika berkorelasi positif. Selfefficacy dalam matematika dapat diartikan sebagai keyakinan siswa akan kemampuan yang dimiliki untuk mengerjakan soal-soal matematika dan menyelesaikan tugas matematika. Self-efficacy siswa sangat penting dalam peme- 
cahan masalah karena akan mempengaruhi keyakinan siswa dalam setiap langkah-langkah penyelesaian pemecahan masalah yang dilakukan. Sesuai dengan hasil penelitian Hacket, 1985; Pajares, 1996a; Pajares \& Miller,1994 (Pajares \& Miller, 1997, p. 214) menunjukkan bahwa persepsi siswa mengenai kemampuan pemecahan masalah matematika sesuai dengan kemampuan mereka sebenarnya dalam memecahkan masalah. Selain itu, hasil penelitian yang telah dilakukan Pimta, Tayruakham \& Nuangchalerm (2009, p. 381) self-efficacy menunjukkan secara tidak langsung salah satu aspek yang berpengaruh terhadap kemampuan pemecahan. Hal ini sejalan dengan pendapat Pajares \& Kranzler (Pajares \& Miller, 1997:214) bahwa self-efficacy telah terbukti sebagai prediktor yang kuat dalam kemampuan pemecahan masalah matematika.

Hasil observasi pendahuluan melalui wawancara kepada beberapa guru matematika dan siswa di Kabupaten Ciamis diperoleh informasi guru jarang memberikan soal masalah non rutin, karena dalam proses pembelajaran kebanyakan siswa hanya mengingat bukan memahami konsep, sehingga siswa bingung ketika menghubungkan informasi yang tersaji dalam soal dengan konsep yang mungkin dalam penyelesaian soal pemecahan masalah. Kebanyakan siswa mementingkan jawaban akhir dibandingkan proses penyelesaian pada soal pemecahan masalah. Terlebih lagi jika soal yang diberikan berbeda dengan contoh, menyebabkan ketidakyakinan siswa dalam menyelesaikan soal yang sedang dihadapi. Masih banyak persepsi siswa terhadap matematika adalah pelajaran yang sulit. Ketika menemukan hal yang dianggap kurang paham, siswa lebih memilih diam tidak berani bertanya. Keadaan ini berdampak pada self-efficacy siswa masih rendah.

Dari uraian tersebut, secara teoritis kemampuan pemecahan masalah dan self eficacy terdapat hubungan yang saling berpengaruh dan berperan penting untuk mencapai tujuan pembelajaran. Belum adanya penelitian yang serupa dilakukan di Kabupaten Ciamis, hal ini memotivasi dan menjadi alasan dasar peneliti untuk melakukan penelitian yang berkaitan dengan kemampuan pemecahan masalah dan selfefficacy siswa di Kabupaten Ciamis. Diharapkan dari penelitan ini memberikan informasi mengenai kemampuan pemecahan masalah matematika dan self-efficacy siswa, sehingga mampu meningkatkan kualitas mengajar guru dan menjadi salah solusi untuk memperbaiki kondisi pendi- dikan di Kabupaten Ciamis. Dengan demikian penelitian ini bertujuan untuk mendeskripsikan kemampuan pemecahan masalah matematika, self-efficacy siswa dan hubungan antara kemampuan pemecahan masalah dan self-efficacy siswa kelas VIII SMP Negeri di Kabupaten Ciamis.

\section{METODE}

Jenis penelitian ini termasuk penelitian survei. Pada penelitian ini dianalisis kemampuan pemecahan masalah matematika dan selfefficacy siswa SMP Negeri di Kabupaten Ciamis khususnya kelas VIII. Penelitian ini dimulai pada 7 Februari sampai 10 Maret 2017. Populasi pada penelitian ini siswa kelas VIII SMP Negeri di Kabupaten Ciamis sebanyak 79 sekolah dengan ukuran populasi 11.602 siswa. Teknik pengambilan sampel yang digunakan adalah stratified proportional random sampling. Dari 79 sekolah di Kabupaten Ciamis terdapat 5 sekolah yang berada pada kategori tinggi, 66 sekolah pada kategori sedang, dan 8 sekolah pada strata rendah. Dalam penelitian ini ada 13 sekolah yang dipilih berdasarkan strata yaitu 1 sekolah pada kategori tinggi, 11 sekolah pada kategori sedang, dan 1 sekolah pada kategori rendah. Diperoleh sampel penelitan sebanyak 389 siswa.

Teknik pengumpulan data yang dilakukan dalam penelitian ini adalah tes dan angket yang diberikan satu kali. Pengumpulan data untuk mengukur kemampuan pemecahan masalah diperoleh dengan menggunakan soal-soal pemecahan masalah non rutin berbentuk uraian, sedangkan untuk mengukur self-efficacy siswa terhadap belajar matematika dan dalam menyelesaikan soal-soal matematika.

Instrumen digunakan untuk memperoleh data yang digunakan untuk menjawab penelitian. Adapun soal yang digunakan dalam tes diagnostik sebagai berikut:

\section{Soal 1:}

Atika adalah seorang sales dari produk makanan ringan. Perusahaan tempat Atika bekerja, menargetkan para sales agar setiap hari menambah 2 pelanggan dari hari sebelumnya. Jika selama seminggu Atika menargetkan untuk mendapat 56 pelanggan, maka berapa jumlah pelanggan yang harus didapat Atika pada hari ketujuh?

\section{Soal 2:}

Berikut ini adalah data nilai hasil ujian siswa kelas VII-B untuk mata pelajaran matematika. Nilai siswa diurutkan dari yang terendah ke yang tertinggi: $4,4,4,5,5,5,5,5,6,6,6,6,7$, 
7, 7, 7, 7, 7, 8, 9. Menurut pertimbangan guru, siswa harus mengulang ujian kembali untuk memperbaiki nilai apabila nilai yang mereka dapatkan kurang dari rata-rata nilai kelas. Berapa banyak siswa yang harus memperbaiki nilai ujian matematika?

Soal 3:

Pak Narto memiliki sebidang tanah yang berbentuk trapesium, seperti gambar berikut. Beliau akan menjual tanah tersebut dengan harga Rp 560.000.000. Tentukan harga setiap meter persegi tanah Pak Narto!

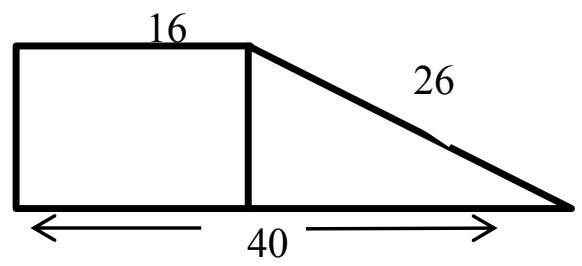

Soal 4:

Nina melempar sebuah dadu sebanyak 30 kali pelemparan, diperoleh 10 kali muncul mata dadu 1, 8 kali muncul mata dadu 2, 5 kali muncul mata dadu 3, dan 2 kali muncul mata dadu 4, 3 kali muncul mata dadu 5 dan 2 kali muncul mata dadu 6. Tentukan peluang empirik muncul mata dadu kurang dari mata dadu 4 !

Soal 5:

Ketika bel istirahat berbunyi, Nina, Reni dan Siska pergi ke kantin sekolah. Nina membeli 2 puding dan 3 kue brownis, total harga yang harus dibayar Nina sebanyak Rp. 16.500. Sedangkan Reni membeli 2 puding dan 1 kue brownis harus membayar Rp. 12.500. Jika Siska membeli 4 puding dan 2 kue brownis, berapa belanjaan Siska yang harus dibayar?

Selain itu, kisi-kisi angket self-efficacy siswa yang digunakan dalam penelitian ini disajikan pada Tabel 2.

Tabel 2. Kisi-Kisi Angket Self-efficacy

\begin{tabular}{cl}
\hline Aspek & \multicolumn{1}{c}{ Indikator } \\
\hline Level & $\begin{array}{l}\text { Keyakinan dalam strategi yang } \\
\text { digunakan } \\
\text { Keyakinan dalam berbagai tingkat } \\
\text { kesulitan }\end{array}$ \\
Kenerality & $\begin{array}{c}\text { Keyakinan diri pada } \\
\text { seluruh proses pembelajaran } \\
\text { Keyakinan dalam menghadapi kondisi } \\
\text { dan situasi yang beragam } \\
\text { Keyakinan akan usaha yang dilakukan } \\
\text { Keyakinan memperoleh hasil yang baik }\end{array}$ \\
\hline
\end{tabular}

Keabsahan data dalam penelitian ini dilakukan dengan uji validitas dan reliabilitas baik instrumen tes diagnostik maupun angket. Bukti validitas instrumen yang akan digunakan dalam penelitian ini adalah validitas isi (content validity). dan validitas konstruk (conctruc validity). Validasi isi dilakukan oleh dua orang dosen pendidikan matematika UNY. Sedangkan, validitas konstruk dilakukan analisis faktor dengan bantuan SPSS 20. Berdasarkan hasil analisis faktor setelah dilakukan uji coba angket selfefficacy, diperoleh nilai KMO sebesar 0,706 artinya analisis faktor dapat diteruskan nilai signifikansi $0,000<0,05$ artinya bahwa data yang diperoleh valid. Selanjutnya untuk hasil reliabilitas instrumen angket self-efficacy menunjukkan nilai cronbach's alpha 0,753 dan reliabilitas instrumen tes kemampuan pemecahan masalah matematika menunjukkan nilai cronbach's alpha 0,656. Hal ini menunjukkan tes dikatakan reliabel sesuai pernyataan Ebel \& Frisbie (199, p.86) tes skor reliabilitas diterima jika standar minimal mencapai 0,65 .

Dalam penelitian ini, teknik analisis data yang digunakan adalah analisis kuantitafifkualitatif. Analisis digunakan untuk memperoleh deskripsi dari kemampuan siswa dalam memecahkan masalah matematika dan angket selfefficacy siswa terhadap pemecahan masalah matematika, serta hubungan antara kemampuan pemecahan masalah dan self-efficacy siswa terhadap matematika.

Sebelum menganalisis data dengan pendekatan kualitatif, penelitian melakukan analisis dengan pendekatan kuantitatif, yaitu agar mengetahui hasil kemampuan pemecahan masalah siswa, persentase kemampuan pemecahan matematika siswa, self-efficacy siswa terhadap matematika, serta hubungan antara kemampuan pemecahan masalah siswa dan self-efficacy siswa terhadap matematika. Pendekatan kuantitatif bertujuan agar memudahkan peneliti dalam menganalisis data yang akan digunakan untuk mengetahui kemampuan pemecahan masalah matematika siswa dan self-efficacy siswa.

Langkah-langkah yang dilakukan dalam menganalisis data pada penelitian ini, yaitu pertama mengumpulkan dan memformulasikan semua data yang diperoleh selama di lapangan, dengan memeriksa hasil angket self-efficacy (selalu, sering, kadang-kadang, jarang, tidak pernah) dan hasil tes uraian dalam menyelesaikan soal (menjawab benar, benar tapi kurang lengkap, ada kesalahan, tidak menjawab). Selanjutnya, menganalisis hasil angket dan tes berdasarkan indikator-indikator yang ditetapkan. Menggelompokan skor yang diperoleh sesuai 
kriteria menggunakan skala lima. Kemudian, menganalisis tingkat hubungan antara kemampuan pemecahan masalah matematika dan selfefficacy siswa, dengan melihat nilai $r$ hasil output product moment pearson. Interprestasi koefisiensi korelasi disajikan pada Tabel 3.

Tabel 3. Interpretasi Koefisiensi Korelasi

\begin{tabular}{cc}
\hline Koefisien Korelasi & Keterangan \\
\hline $0,80 \leq r_{x y}<1,00$ & Sangat Tinggi \\
$0,60 \leq r_{x y}<0,80$ & Tinggi \\
$0.40 \leq r_{x y}<0,60$ & Sedang \\
$0,20 \leq r_{x y}<0.40$ & Rendah \\
$0,00 \leq r_{x y}<0,20$ & Sangat Rendah \\
\hline
\end{tabular}

Kedua, menganalisis lebih mendalam dalam secara deskriptif. Analisis data dilakukan pada setiap soal uraian untuk mengetahui kemampuan pemecahan masalah siswa. Sedangkan analisis data untuk angket dilakukan untuk mengetahui self-efficacy siswa terhadap matematika serta melihat ada atau tidaknya hubungan antara kemampuan pemecahan masalah dan selfefficacy siswa.

Ketiga, penarikan kesimpulan dengan pendekatan kualitatif. Analisis kualitatif digunakan untuk memperoleh deskripsi informasi mengenai kemampuan pemecahan masalah matematika siswa dalam mengerjakan soal non rutin dan mendeskripsikan self-efficacy siswa terhadap matematika serta ada atau tidaknya hubungan antara kemampuan pemecahan masalah matematika dan self-efficacy siswa, sehingga lebih mudah ditafsirkan sesuai dengan rumusan masalah.

\section{HASIL DAN PEMBAHASAN}

\section{Deskripsi Hasil}

Dalam penelitian ini peneliti mengumpulkan informasi berdasarkan hasil penelitian yang diperoleh dari angket self-efficacy dan tes diagnostik mengenai kemampuan pemecahan masalah matematika siswa. Pendeskripsian akan difokuskan mengenai self-efficacy siswa, kemampuan pemecahan masalah matematika berdasarkan polya serta hubungan antara kemampuan pemecahan masalah dan selfefficacy.

Angket self-efficacy yang diberikan kepada siswa terdiri dari 30 item dengan setiap item memiliki skor 0-5, sehingga total skor selfefficacy memiliki rentang 0-150. Data pengukuran self-efficacy siswa di setiap sekolah disajikan pada Tabel 4.

Rata-rata skor self-efficacy siswa dari 3 strata sekolah yaitu starat tinggi, strata sedang dan strata rendah berada pada kriteria sedang, namun dengan rata-rata yang berbeda. Strata sedang memiliki rata-rata skor self-efficacy tertinggi, yaitu 91,90. Sedangkan strata tinggi memiliki rata-rata skor self-efficacy terendah, yaitu 89,3. Secara keseluruhan rata-rata dari strata tinggi, strata sedang dan strata rendah berada dalam kriteria sedang, yaitu sebesar 91,70

Selain self-efficacy siswa secara keseluruhan, penelitian juga menganalisis self efficcay siswa berdasarkan tiap aspek meliputi level, generality dan strength akan disajikan pada Tabel 5.

Tabel 4. Deskripsi Data Self-efficacy Siswa pada Tiap Strata

$\begin{array}{ccccc}\text { Deskripsi } & \text { Strata Tinggi } & \text { Strata Sedang } & \text { Strata Rendah } & \text { Keseluruhan } \\ \text { Kriteria } & \text { Sedang } & \text { Sedang } & \text { Sedang } & \text { Sedang } \\ \text { Rata-Rata } & 89,3 & 91,90 & 91,6 & 91,71 \\ \text { Standar Deviasi } & 7,85 & 14,92 & 8,7 & 14,20 \\ \text { Skor tertinggi yang mungkin } & 150 & 150 & 150 & 150 \\ \text { Skor terendah yang mungkin } & 30 & 30 & 30 & 30 \\ \text { Skor tertinggi yang dicapai } & 111 & 139 & 110 & 139 \\ \text { Skor terendah yang dicapai } & 72 & 35 & 78 & 35\end{array}$

Tabel 5. Deskripsi Dimensi Self-efficacy pada Tiap Strata

\begin{tabular}{cccccc}
\hline Aspek & Deskripsi & Strata Tinggi & Strata Sedang & Strata Rendah & Keseluruhan \\
\hline \multirow{2}{*}{ Level } & Rata-rata & 26,64 & 27,10 & 27,04 & 27,06 \\
& Kriteria & Sedang & Sedang & Sedang & Sedang \\
\multirow{4}{*}{ Generality } & Rata-rata & 30,32 & 30,66 & 30,46 & 30,62 \\
& Kriteria & Sedang & Sedang & Sedang & Sedang \\
\multirow{2}{*}{ Strength } & Rata-rata & 32,36 & 34,15 & 34,07 & 34,02 \\
& Kriteria & Sedang & Sedang & Sedang & Sedang \\
\hline
\end{tabular}


Dari Tabel 5, diperoleh informasi bahwa aspek level, rata-rata keseluruhan mencapai 27,06 . Sekolah strata tinggi memperoleh ratarata paling kecil dibandingkan sekolah strata yang lain. Pada aspek generality, rata-rata keseluruhan mencapai 30,62. Sekolah strata tinggi memperoleh rata-rata paling kecil dibandingkan sekolah strata yang lain. Pada aspek strength, rata-rata keseluruhan mencapai 34,04. Sekolah strata sedang memperoleh rata-rata paling tinggi, sedangan sekolah strata tinggi memperoleh rata-rata paling kecil. Namun, secara keseluruhan rata-rata self-efficacy siswa pada tiap aspek berada pada kriteria sedang.

Frekuensi dan persentase banyak siswa pada setiap kriteria self-efficacy siswa terhadap matematika dihitung sesuai dengan rentang skor yang telah ditentukan, hal ini dapat dilihat pada Tabel 6 .

Data pada Tabel 6 menunjukkan, tidak terdapat siswa yang masuk pada kriteria sangat tinggi, hanya 1 orang yang berada pada kriteria tinggi, sedangkan sebagian besar siswa berada pada kriteria sedang sebanyak 21 orang dan 3 orang pada kriteria rendah. Sedangkan jumlah siswa di strata sedang paling banyak diantara strata tinggi dan strata rendah, yaitu sebanyak 336 siswa. Jumlah siswa pada kriteria sangat tinggi sebanyak 14 siswa, sedangkan pada kriteria tinggi sebanyak 62 siswa. Strata sedang didominasi oleh siswa pada kriteria sedang sebanyak 202 siswa, pada kriteria rendah terdapat 47 siswa dan hanya 11 orang yang terdapat pada kriteria sangat rendah. Dari 28 siswa pada strata rendah, tidak terdapat siswa pada kriteria sangat tinggi begitu juga pada kriteria sangat rendah. Siswa yang berada pada kriteria tinggi hanya terdapat 3 siswa, sedangkan pada kriteria sedang sebanyak 21 siswa dan pada kriteia rendah sebanyak 4 orang.

Selanjutnya, pada Tabel 7 menyajikan hasil jenis jawaban tes diagnostik siswa pada tiap butir soal. Tes diagnostik diberikan dalam bentuk soal uraian sebanyak 5 soal pada materi bilangan, statistika, geometri, peluang dan aljabar. Setiap soal yang dikerjakan oleh 389 siswa terdiri atas tahapan polya yang terdiri 4 langkah, namun khusus untuk soal nomor 2 hanya terdiri dari 3 langkah. Hasil dari tes diagnostik siswa yang telah terkumpul, peneliti mengkoreksi untuk melihat banyaknya siswa yang menjawab benar (MB), benar namun kurang lengkap (BK), ada kesalahan (AK), tidak menjawab (TM). Berikut hasil yang diperoleh dari jawaban siswa pada sekolah strata tinggi, strata sedang dan strata rendah kelas VIII SMP Negeri di Kabupaten Ciamis.

Data pada Tabel 7 merupakan pekerjaan siswa pada tiap butir soal, persentase siswa yang tidak menjawab soal yaitu $45.93 \%$, lebih banyak jika dibandingkan dengan jumlah siswa yang menjawab benar yaitu $12,04 \%$, siswa yang menjawab benar tapi kurang lengkap sebanyak $23,75 \%$ dan siswa yang menjawab namun masih ada kesalahan sebanyak $18,27 \%$. Hal ini menunjukkan bahwa banyak siswa belum mampu menyelesaikan soal pemecahan masalah bahkan persentase tertinggi diduduki oleh siswa yang memilih untuk tidak menjawab soal karena ketidakmampuannya menyelesaikan soal.

Tabel 6. Distribusi Frekuensi dan Persentase Kriteria Self-efficacy Siswapada Tiap Strata

\begin{tabular}{cccccccc}
\hline Nama Sekolah & & Sangat Tinggi & Tinggi & Sedang & Rendah & Sangat Rendah & Jumlah \\
\hline \multirow{2}{*}{ Strata Tinggi } & $f$ & 0 & 1 & 21 & 3 & 0 & 25 \\
& $\%$ & 0 & 4 & 84 & 12 & 0 & 100 \\
\multirow{3}{*}{ Strata Sedang } & $f$ & 14 & 62 & 202 & 47 & 11 & 336 \\
& $\%$ & 4,17 & 18,45 & 60,12 & 13,9 & 3,17 & 100 \\
\multirow{2}{*}{ Strata Rendah } & $f$ & 0 & 3 & 21 & 4 & 0 & 28 \\
& $\%$ & 0 & 10,7 & 75 & 14,3 & 0 & 100 \\
\hline
\end{tabular}

Tabel 7. Hasil Jenis Jawaban Tes Diagnostik pada Tiap Butir Soal

\begin{tabular}{|c|c|c|c|c|c|c|c|}
\hline \multirow{2}{*}{ Jenis Jawaban } & & \multicolumn{5}{|c|}{ Jumlah Siswa (\%) } & \multirow{2}{*}{ Jumlah } \\
\hline & & Soal 1 & Soal 2 & Soal 3 & Soal 4 & Soal 5 & \\
\hline \multirow{2}{*}{ Benar (MB) } & $f$ & 288 & 115 & 115 & 157 & 215 & 890 \\
\hline & $\%$ & 18,51 & 9,85 & 7,39 & 10,09 & 13,82 & 12,04 \\
\hline \multirow{2}{*}{ Benar tapi kurang lengkap (BK) } & $f$ & 523 & 439 & 292 & 238 & 263 & 1955 \\
\hline & $\%$ & 33.61 & 37,62 & 18,77 & 15,30 & 16,90 & 23,75 \\
\hline \multirow{2}{*}{ Ada Kesalahan (AK) } & $f$ & 299 & 381 & 418 & 145 & 107 & 1350 \\
\hline & $\%$ & 19,22 & 32,65 & 26,86 & 9,32 & 6,88 & 18,27 \\
\hline \multirow{2}{*}{ Tidak Menjawab (TM) } & $f$ & 445 & 232 & 731 & 1016 & 971 & 3395 \\
\hline & $\%$ & 28,60 & 19,88 & 46,98 & 65,30 & 62,40 & 45,93 \\
\hline
\end{tabular}


Data hasil pengukuran kemampuan pemecahan masalah siswa secara keseluruhan di setiap strata sekolah akan disajikan pada Tabel 8. Data pada Tabel 8 menunjukkan bahwa setiap strata sekolah memiliki rata-rata yang berbedabeda, walaupun tidak ada strata sekolah yang mencapai kriteria sangat tinggi, maupun tinggi. Fakta menunjukkan siswa kurang mampu dalam menyelesaikan soal-soal pemecahan masalah. Kemampuan pemecahan masalah siswa pada sekolah starta tinggi berada pada kriteria sedang yaitu dengan rata-rata mencapai 23,08 dengan skor tertinggi yaitu 34 dan skor terendahnya adalah 13, sedangkan kemampuan pemecahan masalah siswa pada strata sedang dan strata rendah memiliki kriteria yang sama, yaitu rendah. Sekolah strata sedang memperoleh rata-rata 19,3 dengan skor tertinggi yaitu 42 dan skor terendah adalah 2. Selanjutnya, sekolah strata rendah mencapai rata-rata 14,5 . Skor tertinggi yang dicapai siswa yaitu 27 dan skor terendah adalah 7 .

Frekuensi dan persentase banyak siswa pada setiap kriteria kemampuan pemecahan masalah matematika dihitung sesuai dengan rentang skor yang telah ditentukan, hal ini dapat dilihat pada Tabel 9. Data pada Tabel 9 menunjukan informasi mengenai frekuensi dan persentase kemampuan pemecahan masalah siswa di setiap strata sekolah. Hanya ada 2 siswa yang masuk dalam kriteria sangat tinggi, yaitu pada sekolah strata sedang. Subjek penelitian di sekolah strata tinggi sebanyak 25 siswa, namun siswa yang berada pada kriteria tinggi hanya 3 siswa $(12 \%)$, sedangkan pada kriteria sedang sebanyak 10 siswa (40\%), pada kriteria rendah selisih 1 siswa dari kriteria sedang, yaitu sebanyak 11 siswa (44\%) dan 1 siswa (4\%) pada kriteria sangat rendah. Subjek penelitian di sekolah strata sedang sebanyak 336 siswa dan terdapat 2 siswa $(0,6 \%)$ dalam kriteria sangat tinggi. Siswa yang berada pada kriteria tinggi sebanayak 39 siswa $(11,61 \%)$. Sedangkan siswa yang berada pada kriteria sedang, yaitu sebanyak 99 siswa $(29,46 \%)$ dan pada kriteria rendah mencapai 60 siswa $(17,86 \%)$. Sebagain besar siswa pada strata sedang berada pada kriteria rendah, yaitu sebanyak 136 siswa (40,48\%). Selanjutnya, subjek penelitian di sekolah strata rendah sebanyak 28 siswa dan tidak ada siswa yang berada pada kriteria sangat tinggi, tinggi maupun sedang. Siswa yang berada pada kriteria rendah sebanyak 18 siswa $(64,29 \%)$ dan sisanya berada pada kriteria sangat rendah sebanyak 10 siswa $(35,71 \%)$.

Tabel 8. Deskripsi Data Kemampuan Pemecahan Masalah Matematika Siswa pada Tiap Strata

\begin{tabular}{cccc}
\hline Deskripsi & Strata Tinggi & Strata Sedang & Strata Rendah \\
\hline Kriteria & Sedang & Rendah & Rendah \\
Rata-rata & 23,08 & 19,3 & 14,5 \\
Standar Deviasi & 5,82 & 10,3 & 4,7 \\
Skor tertinggi yang mungkin & 53 & 53 & 53 \\
Skor terendah yang mungkin & 0 & 0 & 0 \\
Skor tertinggi yang dicapai & 34 & 42 & 22 \\
Skor terendah yang dicapai & 13 & 2 & 7 \\
\hline
\end{tabular}

Tabel 9. Distribusi Frekuensi dan Persentase Kriteria Kemampuan

Pemecahan Masalah Matematika Siswa Tiap Stara Sekolah

\begin{tabular}{cccccccc}
\hline Nama Sekolah & & Sangat tinggi & Tinggi & Sedang & Rendah & Sangat rendah & Jumlah \\
\hline \multirow{2}{*}{ Strata Tinggi } & $F$ & 0 & 3 & 10 & 11 & 1 & 25 \\
& $\%$ & 0 & 12 & 40 & 44 & 4 & 100 \\
\multirow{5}{*}{ Strata Sedang } & $F$ & 2 & 39 & 99 & 60 & 136 & 336 \\
& $\%$ & 0,6 & 11,61 & 29,46 & 17,86 & 40,48 & 100 \\
\multirow{2}{*}{ Starta Rendah } & $F$ & 0 & 0 & 0 & 18 & 10 & 28 \\
& $\%$ & 0 & 0 & 0 & 64,29 & 35,71 & 100 \\
\hline
\end{tabular}

Tabel 10. Persentase Kemampuan Pemecahan Masalah Matematika Siswa

Berdasarkan Tahapan Polya

\begin{tabular}{cccc}
\hline Tahap Polya & Rata-Rata & Persentase & Kriteria \\
\hline Memahami Masalah & 7,41 & 49,41 & Sedang \\
Merencanakan Pemecahan Masalah & 5,15 & 34,33 & Rendah \\
Melaksanakan Rencana Masalah & 6,32 & 42,14 & Sedang \\
Memeriksa Kembali & 0,34 & 4,24 & Sangat rendah \\
Keseluruhan & 4,8 & 36,27 & Rendah \\
\hline
\end{tabular}


Jurnal Riset Pendidikan Matematika, 4 (2), 2017 - 173

Ratna Widianti, Dhoriva Urwatul Wutsqa

Tabel 11. Deskripsi Kriteria Tahapan Polya Kemampuan Pemecahan Masalah Matematika Tiap Strata

\begin{tabular}{cccccc}
\hline Sekolah & & $\begin{array}{c}\text { Memahami } \\
\text { Masalah }\end{array}$ & $\begin{array}{c}\text { Merencanakan } \\
\text { Pemecahan Masalah }\end{array}$ & $\begin{array}{c}\text { Melaksanakan Rencana } \\
\text { Pemecahan Masalah }\end{array}$ & $\begin{array}{c}\text { Memeriksa } \\
\text { Kembali Hasil }\end{array}$ \\
\hline \multirow{2}{*}{ Strata Tinggi } & $\%$ & 62,4 & 37,33 & 50,4 & 3,5 \\
& Kriteria & Tinggi & Rendah & Sedang & Sangat Rendah \\
\multirow{2}{*}{ Strata Sedang } & $\%$ & 48,95 & 34,84 & 42,74 & 3,72 \\
& Kriteria & Sedang & Rendah & Sedang & Sangat Rendah \\
\multirow{2}{*}{ Strata Rendah } & $\%$ & 43,33 & 25,48 & 27,62 & 0 \\
& Kriteria & Sedang & Rendah & Rendah & Sangat Rendah \\
\hline
\end{tabular}

Hasil kinerja kemampuan pemecahan masalah siswa secara umum dalam setiap tahapan polya akan disajikan pada Tabel 10 . Berdasarkan Tabel 10 diperoleh informasi kemampuan pemecahan masalah matematika siswa kelas VIII di SMP Negeri Ciamis yang dilihat berdasarkan tahapan polya. Rata-rata secara keseluruhan kemampuan pemecahan masalah matematika siswa dari tahap polya berada pada kriteria rendah.

Frekuensi dan persentase kemampuan pemecahan masalah siswa berdasarkan tahap polya pada tiap strata sekolah dapat dilihat pada Tabel 11. Berdasarkan Tabel 11, diperoleh informasi bahwa kriteria setiap strata sekolah memiliki persentase yang berbeda. Di sekolah strata tinggi kemampuan siswa pada tahap memahami masalah mencapai $62,4 \%$ termasuk kriteria tinggi. Pada tahap merencanakan pemecahan masalah mencapai 37,33\% dengan kriteria rendah. Sedangkan pada tahap melaksankan rencana mencapai 50,4\% dengan kriteria sedang dan pada tahap memeriksa kembali hasilnya mencapai 3,5\% dengan kriteria sangat rendah. Lebih lanjut, kemampuan pemecahan masalah siswa di sekolah strata sedang pada tahap memahami masalah mencapai $48,95 \%$ dengan kriteria sedang, pada tahap kedua, yaitu merencanakan pemecahan masalah mencapai $34,84 \%$ dengan kriteria rendah, sedangkan pada tahap melaksanakan rencana mencapai $42,74 \%$ pada kriteria sedang dan tahap memeriksa kembali hasil siswa hanya mencapai $3,72 \%$ dengan kriteria sangat rendah. Selanjutnya, kemampuan pemecahan masalah siswa pada sekolah strata rendah. Pada tahap memahami masalah mencapai $43.33 \%$ dengan kriteria sedang, pada tahap merencanakan pemecahan masalah mencapai $25,48 \%$ dengan kriteria rendah, sedangkan pada tahap melaksanakan rencana mencapai $27,62 \%$ dengan kriteria rendah dan pada tahap memeriksa kembali hasil $0 \%$ karena tidak ada satupun siswa yang menyelesaikan sampai pada tahap ini.

\section{Pembahasan}

Data yang disajikan pada Tabel 8, Tabel 9 dan Tabel 10 menunjukkan bahwa siswa kelas VIII SMP Negeri di Kabupaten Ciamis memiliki kemampuan pemecahan yang rendah. Siswa masih belum mampu menyelesaikan soal tes diagnostik yang diberikan. Hal ini disebabkan karena siswa belum menguasai materi yang dipelajari, siswa belum terbiasa menyelesaikan soal non rutin, siswa belum mampu memahami konsep untuk menyelesaikan pemecahan masalah dan siswa merasa cukup memperoleh hasil akhir tanpa memeriksa kembali.

Kemampuan pemecahan masalah siswa dapat meningkat dengan membiasakan mereka menyelesaikan masalah non rutin. Dalam kajian Prakitipong \& Nakamura (2006, p.113) dalam proses pemecahan masalah ada banyak faktor yang mendukung siswa untuk mampu menjawab benar, namun ada 2 hambatan yang membuat siswa tidak mampu menjawab benar, yaitu: masalah dalam pemahaman konsep yang berkaitan dengan memahami makna dari permasalahan, dan masalah dalam proses matematika yang terdiri dari transformasi, keterampilan dan proses. Menurut pernyataan tersebut, siswa harus mampu dan terbiasa memahami informasi yang diminta pada soal, selain itu juga pentingnya pengetahuan dan keterampilan siswa dalam proses menyelesaikan soal bukan hanya pada hasil akhir. Berikut ini penjelasan mengenai halhal yang berkaitan dengan kemampuan pemecahan masalah matematika berdasarkan tahap polya:

\section{Memahami Masalah}

Kemampuan siswa dalam menentukan apa yang diketahui dan ditanyakan merupakan tahap yang paling banyak dikerjakan oleh siswa, namun demikian, sebagian siswa masih menunjukkan belum mampu menerapkan informasi pada soal untuk memecahkan masalah, siswa tidak mampu menganalisis informasi pada soal yang diberikan untuk memecahkan maslah, terlebih siswa banyak yang belum mampu 
menentukan kecukupan informasi pada soal. Situasi tersebut merupakan fakta yang lazim ditemukan di lapangan. Menurut Newman (White, 2005,p.17), siswa yang mampu membaca kata dalam soal tidak lantas mampu memahami penguasaan kata-kata tersebut. Terkait dengan hal tersebut, memahami bahasa dan model matematis memang merupakan hal yang tidak dikuasai oleh semua siswa. Menurut Geary (2004, p.4), siswa memiliki kemampuan yang kurang dalam memproses informasi dalam satu atau semua domain matematika.

\section{Merencanakan Pemecahan Masalah}

Tahap merencanakan pemecahan masalah berada pada kriteria rendah berdasarkan persentase langkah polya. Menurut Newman (White, 2000 , p. 17) siswa yang sudah mampu memahami apa yang diinginkan soal belum tentu mampu mengidentifikasi pola/operasi yang dibutuhkan untuk memecahkan soal tersebut. Keadaan ini sesuai hasil penelitian Sari \& Wijaya (2017, p.105) bahwa banyak siswa sulit menganalisis fakta yang ada pada soal untuk dikaitkan dengan konsep matematis yang relevan sehingga siswa salah mentransformasikan masalah pada model matematika.

Ketidakmampuan siswa dalam merencanakan pemecahan masalah dapat terlihat ketika siswa salah dalam memilih rumus atau konsep yang akan digunakan dalam menyelesaikan soal.

\section{Melaksanakan Pemecahan Masalah}

Ketidakmampuan siswa dalam melaksanakan pemecahan masalah yang paling banyak ditunjukkan ketika menentukan hubungan antara informasi yang terdapat pada soal dengan rumus/konsep yang harus digunakan. Sebagian besar siswa merasa bingung ketika mengaitkan hubungan antara apa yang diketahui pada soal dan langkah penyelesaian yang harus dilakukan, sehingga siswa sering salah dalam menyelesaikan soal, tidak sesuai dengan rumus yang ditulis pada tahap merencanakan pemecahan masalah. Keadaan ini sesuai pernyataan Newman (White, 2005 , p.17) yaitu sangat mungkin terjadi pada siswa yang mampu mengidentifikasi operasi atau pola operasi pada soal, tetapi tidak mampu menyelesaikan operasi secara tepat.

\section{Memeriksa Kembali Hasil}

Kemampuan siswa dalam tahap memeriksa kembali dapat ditunjukkan pada saat siswa mensubstitusikan hasil yang telah diperoleh atau menggunakan rumus lain. Persentase kemampuan siswa dalam tahap ini paling kecil dibandingkan dengan tahap polya yang lainnya. Kebanyakan siswa tidak menghiraukan perintah pada soal untuk tahap memeriksa kembali, siswa merasa cukup dengan perolehan hasil akhir tanpa menganalisis kembali dan juga banyak siswa kebingungan untuk melakukan substitusi hasil yang diperoleh apalagi untuk mencari rumus lain.

Sedangkan untuk hasil self-efficacy siswa, secara keseluruhan rata-rata self eficacy siswa kelas VIII SMP Negeri di Kabupaten Ciamis berada pada kriteria sedang, diharapkan kemampuan pemecahan masalah matematika siswa juga berada kriteria sedang, namun pada kenyataannya berbeda. Kemampuan pemecahan masalah matematika siswa berada pada kriteria rendah. Keadaan yang terjadi tidak sesuai dengan pernyatan Pajares (2005, p.339) bahwa self-efficacy memberikan dasar untuk memotivasi, bertindak baik dan berprestasi dalam semua bidang kehidupan. Namun menurut Schunk (2012, p. 164) siswa yang memiliki kelemahan dalam belajar menunjukkan interaksi antara selfefficacy dan faktor-faktor lingkungan. Beberapa faktor yang diduga menyebabkan kemampuan pemecahan masalah siswa sangat rendah diantaranya, siswa belum terbiasa menyelesaikan soal pemecahan masalah non rutin, siswa mudah menyerah dalam menyelesaikan soal, siswa kurang teliti dalam menyelesaikan soal, siswa kurang aktif untuk bertanya ketika menemukan hal-hal yang dianggap sulit, metode pembelajaran yang diterapkan guru kurang meningkatan keaktifan siswa dalam belajar, sehingga keadaan ini berdampak pada hubungan kemampuan pemecahan masalah matematika dan selfefficacy siswa yang dilihat menggunakan interpretasi terhadap koefisien korelasi yang diperoleh atau nilai $r$. Koefisien korelasi hu-bungan kemampuan pemecahan masalah matematika dengan self-efficacy siswa kelas VIII SMP Negeri di Kabupaten Ciamis termasuk kategori sangat rendah karena nilai $r$ menun-jukkan 0,104 .

\section{SIMPULAN}

Berdasarkan penelitian dan pembahasan, maka dapat disimpulkan bahwa Kemampuan pemecahan masalah matematika siswa kelas VIII SMP Negeri di Kabupaten Ciamis berada pada kriteria rendah. Berdasarkan tahap polya, kemampuan pemecahan masalah pada tahap memahami masalah $49,41 \%$ berada pada kriteria 
sedang, tahap merencanakan pemecahan masalah $34,33 \%$ berada pada kriteria rendah, tahap melaksanakan rencana masalah $42,14 \%$ berada pada tahap sedang dan tahap memeriksa kembali hasil 4,24\% berada pada kriteria sangat rendah. Sedangkan, self-efficacy siswa kelas VIII SMP Negeri di Kabupaten Ciamis berada pada kriteria sedang, dengan rata-rata 91,17. Berdasarkan aspek self-efficacy, secara keseluruhan siswa berada pada kriteria sedang namun dengan rata-rata yang berbeda. Siswa pada aspek level mencapai rata-rata 27,01 , sedangkan pada aspek generality siswa mencapai rata-rata 30,62 dan pada aspek strength siswa mencapai rata-rata 34,02. Hubungan kemampuan pemecahan masalah matematika dan self-efficacy siswa dilihat menggunakan interpretasi terhadap koefisien korelasi yang diperoleh atau nilai $r$. Koefisien korelasi hubungan kemampuan pemecahan masalah matematika dengan selfefficacy siswa kelas VIII SMP Negeri di Kabupaten Ciamis termasuk kategori sangat rendah karena nilai $r$ sebesar 0,104 .

\section{DAFTAR PUSTAKA}

Bandura, A. (2009). Self-efficacy in changing societies. Cambridge, UK: Cambridge University press.

Ebel, R.L. \& Frisbie, D.A. (1986). Essential of educational measurement. New Jerseey: Prentice- Hall, Inc.

Geary, D.C. (2004). Mathematics and learning disabilities. Jurnal of Learning Disabilities, 37(1), 4-15.

Liu, X. \& Koirala, H. (2009). The effect of mathematics self-efficacy on mathematics achievement of high school students. NER Conference Proceedings, 10(30).

Lunenburg, F. C.(2011).Self-efficacy in the workplace: implication for motivation and performance. International Journal of Management, Bussissnes, and Administration. 14(1),1-6.

National Council of Teachers of Mathematics. (2000). Principles and standars for school mathematics.Reston, VA:The National Council of Teachers of Mathematics, Inc.

Nitko, A. J. (2011). Educational Assessment of Student. Englewood Cliffs. NJ: Merrill Prentice Hall, Inc.
Pajares, F. \& Miller, M.D.(1997). Mathematics self-efficacy and mathematical problemsolving implication of using different forms of assesment. The Journal of Experimental Education, 65(3), 213-228.

Permendikbud. (2016). Salinan Lampiran Peraturan Menteri Pendidikan dan Kebudayaan Nomor 58 Tahun 2014 Tentang Kurikulum 2013 Sekolah Menengah Pertama/Madrasah Tsanawiyah.

Pimta, S. Tayraukham, S. \& Nuangchalerm, P. (2009). Factors Influencing Mathematic Problem-solving Ability of Sixth Grade Students.Journal of social sciences, 5(4), 381-385.

Prakitipong, N. \& Nakamura, S. (2006). Analysis of mathematics performence of grade five students in Thailand using Newman prosedure. Journal international Cooperation in Education, 9, 111-122.

Puspendik. (2012). Kemampuan matematika siswa SMP Indonesia menurut benchmark internasional TIMSS 2011. Jakarta: Kementrian Pendidikan dan Kebudayaan.

Sari, R., \& Wijaya, A. (2017). Mathematical literacy of senior high school students in Yogyakarta. Jurnal Riset Pendidikan Matematika, 4(1), 100-107. doi:http://dx.doi.org/10.21831/jrpm.v4i1. 10649

Schunk, D. (2012). Teori-teori pembelajaran: perspektif pendidikan. (Translated by Eva Hamdiah dan Rahmat Fajar). Yogyakarta: Pustaka Pelajar.

Yates, S.M. (2002). The influence of optimism and pessimism on student achievement in mathematics. Mathematics Education Research Journal, 14(1), 4-15.

Yazgan, Y. (2015). Sixth graders and nonroutine problems: Which strategies are decisive for success. Educational Research and Reviews, 10(13), 18071816.

White, A. L. (2005). Active mathematics in classrooms:finding out why children make mistake and then doing something to help them. Square one, 15,15-19. 